
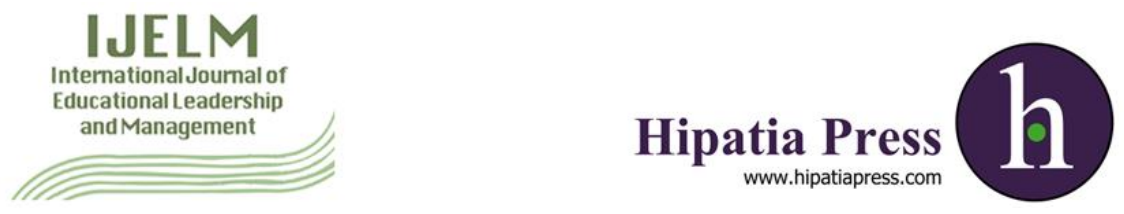

Instructions for authors, subscriptions and further details:

http://ijelm.hipatiapress.com

\title{
Excellence through equity. Five principles of courageous leadership to guide achievement for every student
}

Astrid Salvans $^{1}$

1) Universitat Pompeu Fabra. Spain

Date of publication: January $16^{\text {th }}, 2016$

Edition period: July 2016-January 2017

To cite this article: Salvans, A. (2016). Excellence through equity. Five principles of courageous leadership to guide achievement for every student [Review of the Book Excellence through equity. Five principles of courageous leadership to guide achievement for every student]. International Journal of Educational Leadership and Management, 4(2), 198201. doi: $10.4471 /$ ijelm.2016.2168

To link this article: http://dx.doi.org/10.4471/ijelm.2016.2168

\section{PLEASE SCROLL DOWN FOR ARTICLE}

The terms and conditions of use are related to the Open Journal System and to Creative Commons Attribution License (CC-BY). 


\section{Review}

Blankstein, A.M., \& Noguera, P., with Lorena Kelly. (2016). Excellence through equity. Five principles of courageous leadership to guide achievement for every student. Alexandria, VA: ASCD.

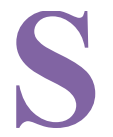

ince the dawn of man, leadership has been related to excellence, but also to some kind of elitism. Excellence through equity is the type of book that changes this perception, reinforcing equity and social justice in the context of leadership.

The book, edited by Blankstein and Noguera (with the help of Lorena Kelly), is preceded with a foreword by Archbishop Desmond Tutu, and shows that it is of our common interest to give all students opportunities to develop their talents and potentials.

The authors and their eighteen contributors (among them academics such as Michael Fullan or Andy Hargreaves), defend a new kind of leadership model, called courageous leadership, and they define this construct as the process to "inspire multitudes, not just a few individuals, to have the courage, commitment and tenacity to lift up those around them" (p. 27).

Throughout the book, the authors claim that excellence can be pursued through equity and that the expansion of equity in education does not mean that those who are advantaged will lose their status. They demand to adopt a new paradigm, a win-win paradigm based on ensuring that all young people 
receive an education that allows them to advance their potential. As the authors say: "Finding ways to do this should be the mission of education, and it is indeed becoming the focus of the most successful schools and districts in America and beyond" (p. 7).

Apart from the introduction (first part) and conclusion of the research (eighth part), Excellence through equity is divided into six parts, in which the authors develop the main framework of courageous leadership.

In part one ("For every Student"), Blankstein and Noguera introduce their book describing equity. As the authors say: "equity is not about treating all children the same" (p. 19) but about addressing the needs of every child and discovering his or her talents. They define equity as "a commitment to ensure that every student receives what he or she needs to succeed" (p. 3). This requires the new kind of leadership, courageous leadership, because in our difficult world there are many arguments for inequity. Being this true, the authors defend the arguments for equity by saying that it is the right thing to do, and also that the alternative to equity is catastrophic.

All these arguments lead us to the main subject of the book: the theoretical and practical development of a new paradigm in which schools try to meet students' needs and build their potential and talents.

From a theoretical point of view, this new paradigm is based on the latest research around child development, neuroscience, and environmental influences on child development and learning. It is also based on some principles of action such as forging collaborative relationships among parents, teachers and administrators; defining what success means for every student; and developing mutual accountability and a shared commitment to the common goal of meeting the needs of all students. The engine that drives the paradigm shift is that of courageous leadership, the type of leadership developed by audacious educators who have contributed to make this ideal a reality.

Courageous leadership means the courage to act, and this implies at the same time to be brave and to be a man or woman with a good heart (coeur in French, this is the root of courage). Courageous leadership is based in five principles that are developed throughout the book: getting to your core, making organizational meaning, ensuring constancy and consistency of purpose, facing the facts and fears, and building sustainable relationships based on respect, trust, and mutual responsibility. 
From a practical point of view, the contributors show very different cases of schools and communities that chose to pursue equity and close instructional and achievement gaps in multicultural K-12 districts and schools. These cases are related to the five principles just mentioned and developed in parts 2 to 6 . Each part corresponds to a principle, and different contributors explain examples of teams of teachers who are determined to change situations.

Although these cases are basically located in North America (Canada and USA), they can easily be applied and replicated in other parts of the world where there are similar challenges (children in poverty, multicultural difficulties, achievement failures etc.). For us, it has been paradigmatic the case around Brocton High School, in Massachusetts, and the lessons learned from its turnaround: to achieve excellence through equity, high expectations for all are essential; however, it is not enough. To achieve excellence through equity, you cannot wait for everyone to buy in before you take action. You have to move!

The authors cover all these subjects adequately through the book combining at the same time an analytical and theoretical approach. There are descriptions of real situations that illustrate the theory and give convincing evidences of the possibility of changing things in deprived schools and neighbourhoods. At the same time, Blankstein and Noguera defy the zero sum myth, arguing that equity is truly the path to excellence for both low- and highachieving students and the K-12 education system overall.

The editors use strong arguments and at the same time they show great knowledge of the situations they describe. In fact, Alan M. Blankstein served for 25 years as president of the HOPE Foundation, which he founded and whose honorary chair is Nobel Prize winner Archbishop Desmond Tutu. He was a former high-risk youth, and founded and directed for 12 years Solution Tree while launching Professional Learning Communities beginning in the late 1980s. Pedro Noguera is a Distinguished Professor of Education Graduate School of Education and Information Sciences at University of California Los Angeles. His research focuses on the ways in which schools are influenced by social and economic conditions, as well as by demographic trends in local, regional and global contexts. He is the author of eleven books and over 200 articles and monographs. So we can properly say that they both know from the inside the situations that they are describing.

The book was published in February 2016 and we strongly recommend to read it and also to use the book in the training of educational leaders. There 
are cases and theory that can be used in leadership programs, and an excellent framework that can be followed to train principals and directors of educational institutions.

Astrid Salvans

Universitat Pompeu Fabra astrid.salvans@upf.edu 